\title{
Relation between Fluidability of Flyash Cement and Properties of Flyash Particles
}

\author{
Hideki Shimada, Akihiro Hamanaka, Takashi Sasaoka, Kikuo Matsui \\ Department of Earth Resources Engineering, Kyushu University, Fukuoka, Japan \\ Email: shimada@mine.kyushu-u.ac.jp
}

Received February 8, 2013; revised March 18, 2013; accepted April 18, 2013

Copyright (C) 2013 Hideki Shimada et al. This is an open access article distributed under the Creative Commons Attribution License, which permits unrestricted use, distribution, and reproduction in any medium, provided the original work is properly cited.

\begin{abstract}
A large amount of waste is produced by preparation plants. The properties of the waste vary depending on the mineralogical contents of the mother rock in which the coal is embedded. The waste quality depends on the method of mining and cleaning. The waste mainly consists of clays, quartz, carbonaceous materials, mica, pyrites, and so on. About $80 \%$ of coal-ash is now utilized and the remainder is disposed of at disposal sites. However, the life span of disposal sites is limited, and it is difficult to find new disposal sites. It is therefore requested that the percentage of utilized flyash be increased in all applicable fields in Japan. Thus, it is very desirable that cement supplemented with flyash be used as injection material for natural/artificial openings. With this perspective in mind, we attempt to clarify how much the size and shape of the flyash affects the properties of the injection mixture by way of an injection test.
\end{abstract}

Keywords: Flyash; Fluidability; Particle Size; Particle Shape

\section{Introduction}

A large amount of coal waste is produced by preparation plants. The properties of the waste vary depending on the mineralogical contents of the mother rock in which the coal is embedded. The waste quality depends on the method of mining and cleaning. The waste mainly consists of clays, quartz, carbonaceous materials, mica, pyrites, and so on. About $80 \%$ of coal-ash is now utilized and the remainder is disposed of at disposal sites [1]. However, the life span of disposal sites is limited. It is therefore requested that the percentage of utilized flyash be increased in all applicable fields in Japan. It is evident, due to problems in finding new disposal sites, that if cement supplemented with flyash can be used as injection material for natural/artificial openings, then the percentage of utilized flyash will be increased.

Among the man-made pozzolans, flyash is probably the most successful component used in mortar injection. When flyash is added to Portland cement concrete, the same kinds of oxides as those of cement are created. As an injection component, flyash acts, in part, as a fine aggregate and, in part, as a binding component. However, heavy bleeding and low fluidity are observed if the cement-flyash water ratio is high. It is necessary to consider a new pozzolan, which can be mixed with flyash and cement to enhance its durability $[1,2]$.
In this paper, we attempt to clarify how much the size and shape of the flyash affects the properties of the injection mixture by way of an injection test.

\section{Engineering Aspects of Backfilling}

The utilization of waste materials in engineering fields is not a new concept. Waste materials have been used throughout the world for many years as backfilling materials to provide additional support to underground caverns. Recently, due to the lack of dumping sites, the use of backfill for regional and local support has been receiving increased attention in the fields of mining and civil engineering.

According to the previous research $[3,4]$, backfilling provides the following benefits to underground coal mines:

- Fills in the excavated areas, promoting better support and ground control.

- Provides better environmental control concerning waste rocks and coal preparation plant wastes.

- Increases coal recovery, especially in room and pillar mining and highwall mining systems.

- Reduces ventilation short-circuiting between adjacent mining sites.

- Reduces the cost of waste transportation to the mine surface dumping sites and tailing ponds, and the cost of associated maintenance and monitoring of these 
facilities.

Also, this concept is applicable to several different areas of civil engineering, such as the filling of large caverns.

\section{Characteristics of Flyash}

The wastes generated from coal burning power plants are flyash, scrubber sludge, ash, spent bed, and fluidized bed wastes. In Japan, these types of wastes are generally called "coal-ash" and classified into two groups: flyash and clinker-ash [5]. In Japan, over 150 million tons of coal is imported and about 50 million tons of coal is burned annually for generating electricity. Approximately 15 percent of all the coal burnt is transformed to coal-ash of which $85 \%$ to $95 \%$ is flyash and $5 \%$ to $15 \%$ is clinkerash. The size of clinker-ash is larger than that of flyash, and therefore, it is crushed before further utilization.

About 55\% of coal-ash is now utilized and the remains are disposed of at disposal sites. However, the life span of these disposal sites are limited, and it is difficult to find new sites for disposal of coal byproducts. It has been requested that the percentage of the utilized coal-ash be increased in all applicable fields in Japan. However, the quality of flyash, depending on the coal type, restricts to how much flyash can be used.

The predominately spherical particle shape of the flyash provides a smooth flow of the mix by acting as a lubricant that decreases the viscosity of the mix, which reduces the wear and tear of the equipment. The particle size range is from less than 0.1 , up to $1 \mathrm{~mm}$, but the majority $(90 \%)$ is less than $0.1 \mathrm{~mm}$.

The addition of flyash also increases the specific surface area per unit weight and produces beneficial aspects on: segregation and rate of settlement, permeability, bleeding and pozzolanic activity.

Moreover, the low heat properties of flyash effectively reduce the temperature of hydration in mixes containing Portland cement by as much as $30 \%$. In Japan, the mixes are called flyash cement and there are three types of Portland flyash cement: class A containing 5\% to $10 \%$ flyash, class B; $10 \%$ to $20 \%$ and class $C ; 20 \%$ to $30 \%$. The mixed cement is cost affective and does not adversely affect the long-term strength of the concrete. The chemical composition of the flyash is shown in Table $\mathbf{1}$.

Additionally, flyash cement is categorized into four types "Type I, II, III and IV" based on the specific area of flyash particle or size distribution [5]. Accordingly, fluidability of injection, density or other properties of each type of flyash cement are very different.

\section{Experiment}

Among the man-made pozzolans, flyash is probably the most successful component to be used in backfilling ma- terials. When flyash is added to Portland cement, the same kinds of oxides as those existent in the cement are being added. As a backfill component, flyash acts, in part, as a fine aggregate and, in part, as a binding component. Fortunately, there is no substantial alteration in the properties of the original component [6,7].

With this in mind, we attempt to clarify how much the size and shape of the flyash affects the properties of the injection mixture by way of an injection test. Table 2 illustrates the contents of each injection mixture. Figure 1 shows the particle size distribution of the Portland cement and two kinds of flyash used for the test. It is shown that the particle size of type II flyash is smaller than that of Portland cement, and that of raw flyash is larger than that of Portland cement. The particle size distribution of Gairome clay, or clay for ceramic industrial use, is listed as a reference.

Table 1. Chemical composition of flyash.

\begin{tabular}{ccc}
\hline Composition (\%) & Domestic coal & Overseas coal \\
\hline $\mathrm{SiO}_{2}$ & $50-55$ & $40-75$ \\
$\mathrm{Al}_{2} \mathrm{O}_{3}$ & $25-30$ & $15-35$ \\
$\mathrm{Fe}_{2} \mathrm{O}_{3}$ & $4-7$ & $2-20$ \\
$\mathrm{CaO}$ & $4-7$ & $1-10$ \\
$\mathrm{MgO}$ & $1-2$ & $1-3$ \\
$\mathrm{~K}_{2} \mathrm{O}$ & $0-1$ & $1-4$ \\
$\mathrm{Na}_{2} \mathrm{O}$ & $1-2$ & $1-2$ \\
\hline
\end{tabular}

Table 2. Contents of each injection mixture.

\begin{tabular}{cccc}
\hline Sample & Water $(\mathrm{kg})$ & Flyash $(\mathrm{kg})$ Portland cement $(\mathrm{kg})$ \\
\hline Portland cement & 40 & 0 & 4.0 \\
Raw flyash cement & 40 & 0.8 & 3.2 \\
Type II of flyash cement & 40 & 0.8 & 3.2 \\
\hline
\end{tabular}

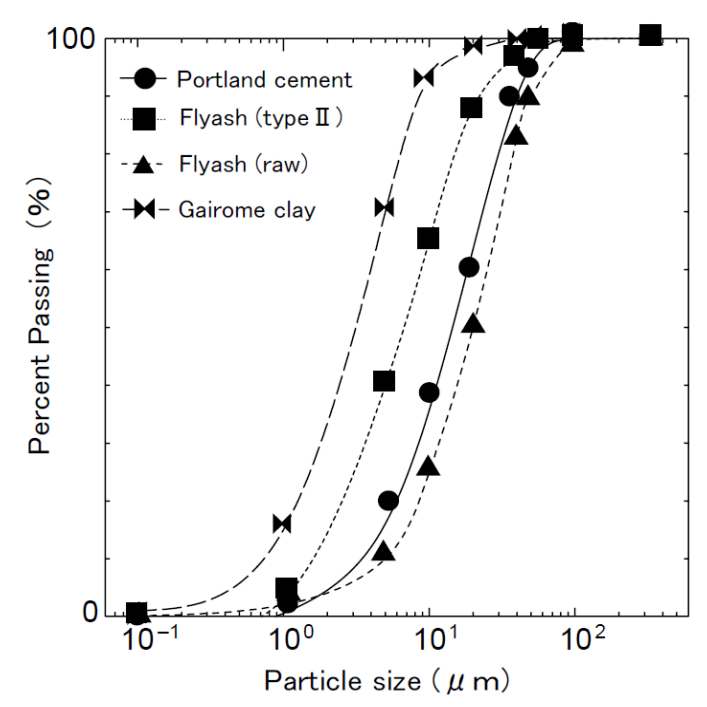

Figure 1. Particle size distribution. 
Figures 2(a) and (b) show the electron microscope photographs of type II flyash and raw flyash. The particles of type II flyash are small bead type, and that of raw flyash are irregular and non-bead type.

\section{Fluidability of Injection of Flyash Cement}

In order to eluidate the seepage/dispersion performance of the grouting material and the filling/clogging process in the soil voids that are blasted, an injection test was performed.

\subsection{Outline of Injection Test}

We discuss whether or not flyash cement has a filtration function while the injection test was being carried out. The schematic diagram of the injection test device used is shown in Figure 3. In this test, glass beads were used as a model of soil and flyash, and Portland cement was employed as an injection material. The procedures of the injection test were as follows: To begin, grouting material was produced in a tank, and the grouting material made of flyash cement was sent to the upper tank at a constant level by a pump.

The grouting material sent to the upper tank was then injected into the beads packed into the cylinder type cell made of stainless steel (the size of the section where the beads were packed $=52 \mathrm{~mm}$ inside diameter and $690 \mathrm{~mm}$ in length). The height of the fluid surface inside the upper tank was regulated, and the grouting material was

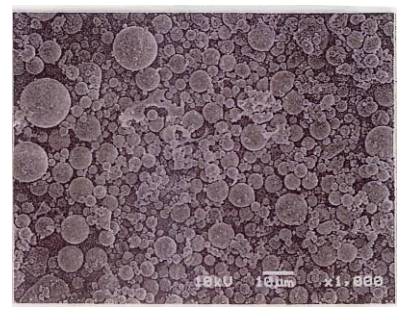

(a) Type II flyash

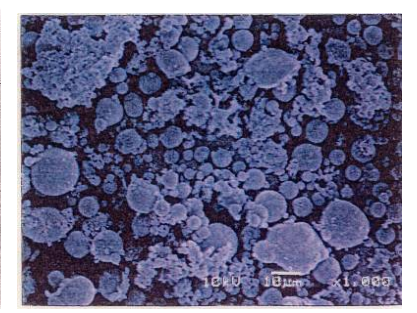

(b) Raw flyash
Figure 2. The electron microscope photographs.

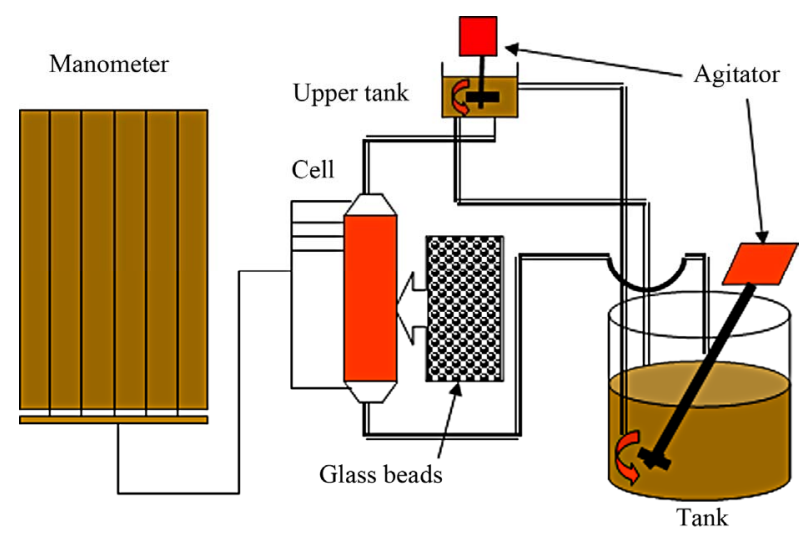

Figure 3. Injection test devices. injected from one direction. At that time, the measuring cylinder measured the discharge flowing out from the cell.

A manometer was installed in the cell to observe the filling conditions of the grouting material. By using the manometer, the change in water head could be measured while grouting material was being injected. The size of the bead particle was $3.96 \mathrm{~mm}-6.68 \mathrm{~mm}$ in diameter, and cement and flyash to water ratio of 1:10 was used during the injection of flyash and Portland cement in this test. The positions of the manometer were 50, 80, 110 and $140 \mathrm{~mm}$ from the inlet (the number of manometer; No.2 - No.5), which was the upper surface of the beads packed into the cell, and each manometer was numbered from 2 to 5 in order of height. The positions of manometers No.1 and No.6 were the top and the bottom of the cell, respectively.

The difference between the water head of the inlet and that of the outlet of the cell was $\Delta \mathrm{h}=1.06 \mathrm{~m}$, and the hydraulic gradient was $\mathrm{i}=\Delta \mathrm{h} / \mathrm{L}=1.54$, where $\mathrm{L}$ was the length of the cell, in this test.

\subsection{Classification of Filling/Clogging Process}

When the grouting material was injected into soil, the injection amount of the grout decreased with the time elapsed after the injection as the soil voids become filled/ clogged with grouting material.

The filling/clogging process was classified into three types [8]. These types are: suspension clogging; suspension custody; and surface filter layer as shown in Figure 2(a). As for the suspension clogging of Figure 4(a), suspended particles, bubbles, etc. block the flow voids. As for the suspension custody of Figure 4(b), flow voids are locally blocked or clogged gradually. As for the surface filter layer of Figure 4(c), suspended particles accumulate at the surface before they filtrate into the voids. Each type depends on the size of the suspended particles and voids. In other words, the particles are filtered with the surface filter layer model of Figure 4(c), if the size of suspended particles is bigger than the voids. Conversely, if the size of the suspended particles is smaller than the voids, they are filtered with the suspension custody model of Figure 4(b). If the size is somewhere in the middle, filtration occurs with the suspension-clogging model detailed in Figure 4(a). Realistically, filtration solely by one of these individual models never occurs. Rather, filtration occurs by a combination of these models.

\subsection{Results of Injection Test}

\subsubsection{Water Head after Injection}

Figures 5-7 show the relationship between the elapsed time after the injection and the water heads of each 


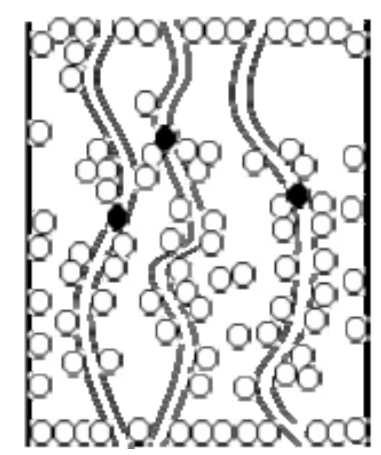

(a) Suspension clogging

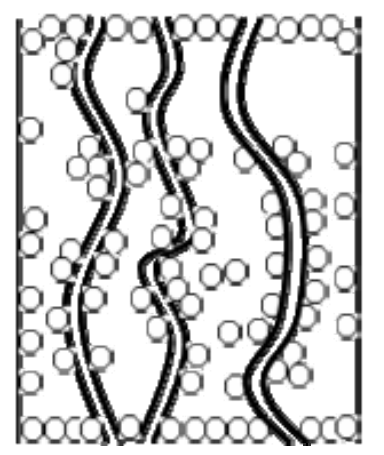

(b) Suspension custody

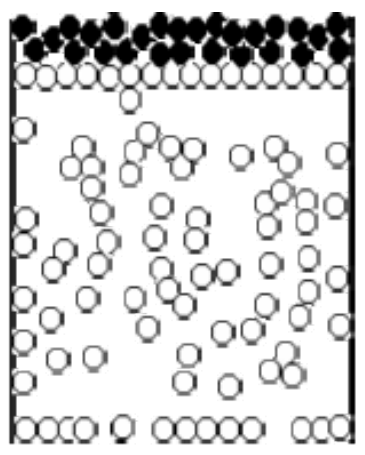

(c) Surface filter layer

Figure 4. Injection test devices.

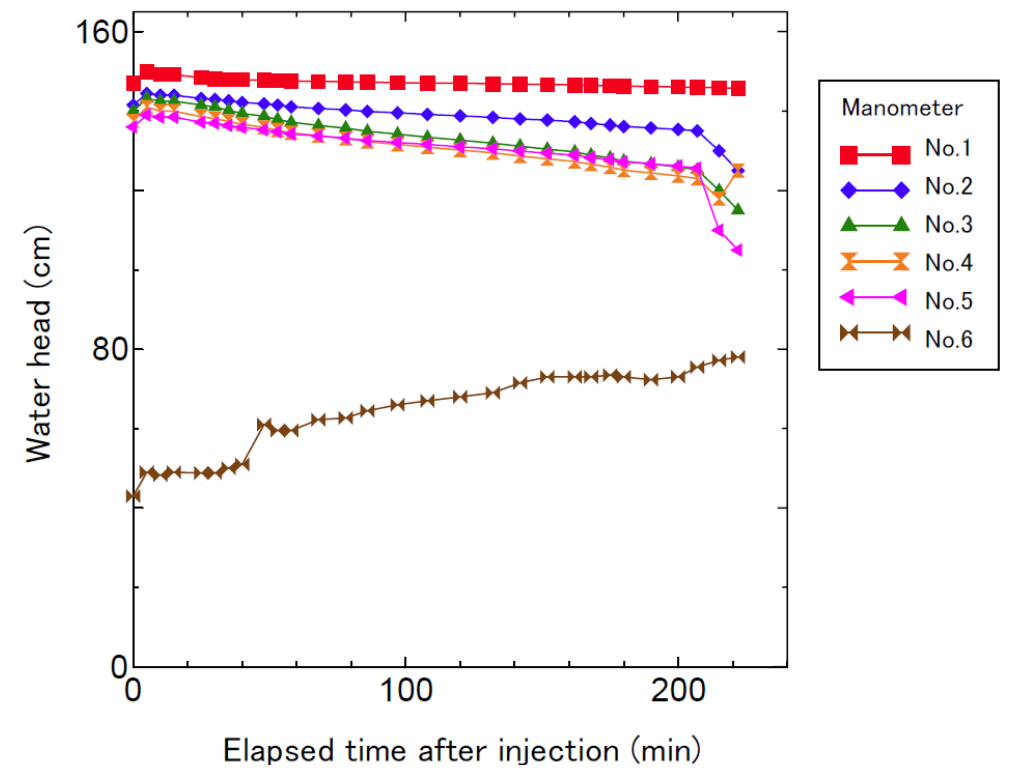

Figure 5. Relationship between the elapsed time after injection and water heads (Portland cement).

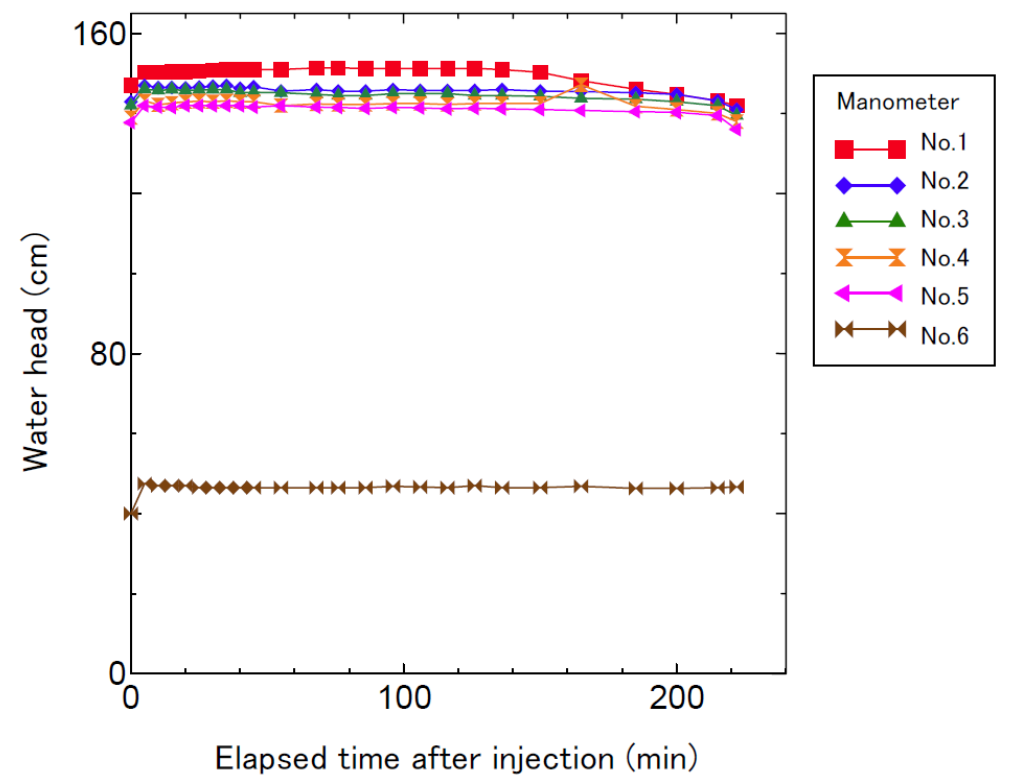

Figure 6. Relationship between the elapsed time after injection and water heads (type II flyash cement). 


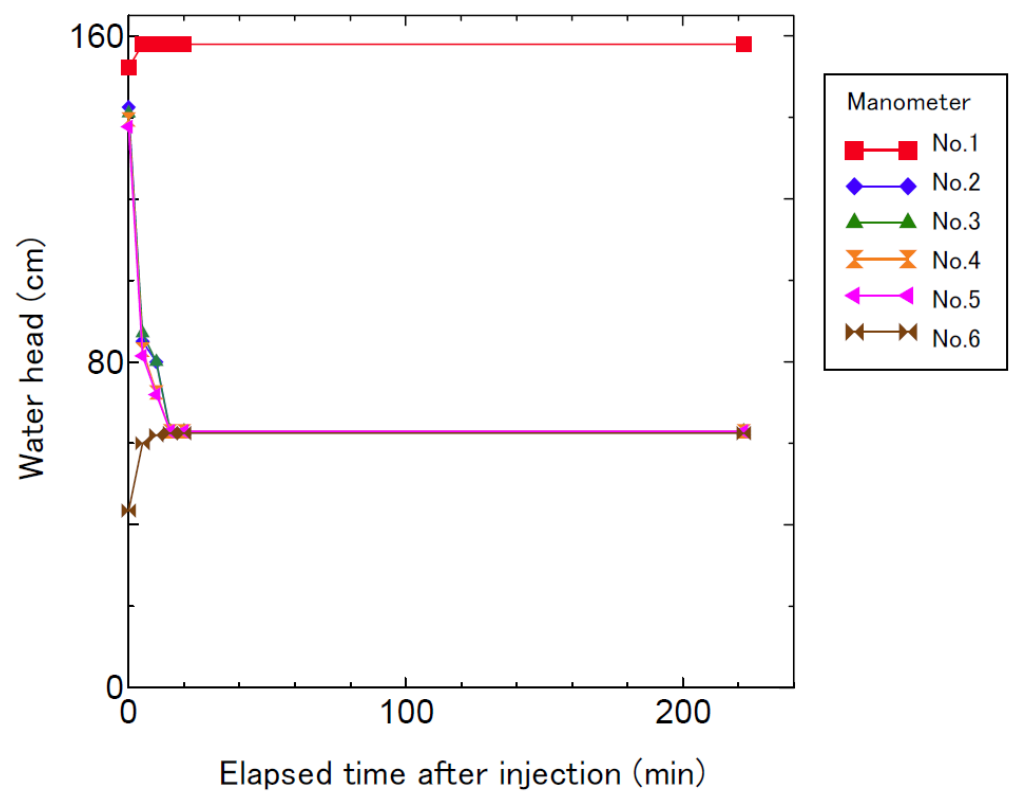

Figure 7. Relationship between the elapsed time after injection and water heads (raw flyash cement).

manometer for Portland cement and two kinds of flyash cement. The water head keeps stable with time in the cases of the Portland cement and the type II flyash cement injection. As the discharge of the injection materials were recognized immediately after the injection, the components of the injection materials filled into the voids gradually as shown in Figure 4(b).

The tendency is more drastic in the case of the raw flyash cement. The size of the particles of raw flyash is larger than the voids of the beads. The flyash particles thus accumulate at the upper surface before they filtrate into the voids over a short time as shown in Figure 4(c). For this reason, the discharge of the injection material was stopped.

\subsubsection{Discharge of Injection Material after Injection}

Figure 8 shows the relationship between the elapsed time after the injection and the discharge of the injection materials. The vertical axis in this figure shows a discharge of injection material $\mathrm{q} / \mathrm{q}_{0}$ normalized in the discharge of water $\mathrm{q}_{0}$ during the permeability test before the injections.

The discharge of the injection materials decreases with time gradually in all cases with regard to all types of injections, as flow voids were locally blocked or clogged.

The discharge of the Portland cement and the type II flyash cement decrease gradually over time after injection, but the rapid decrease of the discharge of the raw flyash after injection was shown in this figure. This difference was considered to be resultant from both the ball bearing action of the spherical particles and the flocculation particle to which chain particles gathered.

That is, when the sodium and the calcium ions which

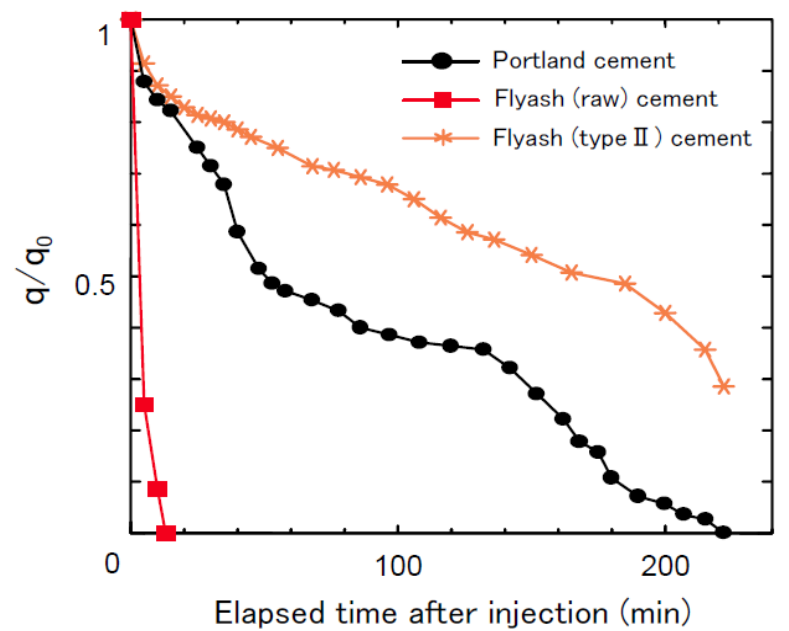

Figure 8. Relationship between elapsed time after injection and discharge of the injection materials.

eluted from cement bond with the negative ions which eluted from the clay component in flyash suspension electrically, flocculation particles were formed as the dispersed particles were gathered. Since the raw flyash with the irregular configuration easily formed on the flocculation particles, the discharge of the injected materials decreased gradually over time in the cases of all types of injections, as flow voids were locally blocked or clogged.

Conversely, when Portland cement and type II flyash cement were used, since flocculation particles were unable to form easily as a result of the grain sizes of both types of cement being small, a ball bearing action could act effectively. For this reason, it seems that the voids were difficult to block even if it filled with both cement 
types over a long period. Moreover, the Portland cement and type II flyash cement are compared. Since the bead's surface tends to adhere to flyash particles, in the case of type II flyash cement, discharge decreased only slightly compared to the Portland cement immediately after injection. However, it is thought possible that after filling for a long duration that the effect of the ball bearing action of a flyash particle becomes more effective. With this perspective in mind, it is concluded that type II flyash cement has a higher fluidability compared with Portland cement.

\subsubsection{Filling Amount of Injection Material}

In order to consider the differences of the filling conditions of the different injection materials, the relation between the filling amount and the distance from the inlet of the cell was considered.

Section I, II and III were defined as: from the inlet of the cell to the position of $17.5 \mathrm{~cm}$ from the inlet, $17.5 \mathrm{~cm}$ to $38.5 \mathrm{~cm}$, and $38.5 \mathrm{~cm}$ to $59.5 \mathrm{~cm}$, respectively. The weights of each injection material per the length of cell section were measured.

Figure 9 shows the weight of the injection material for each section. It is clear that the filling amount decreases with the distance from the inlet for all injection materials. This is because all injections were filtrated from the upper part of the cell and the injection material was filled gradually. The filling amounts of each of the injection materials were highest for section I, as the weights included the suspended particles accumulated at the surface before they filtrate into the voids. The filling amount of the Portland cement was highest, and that of the raw flyash cement was second followed by the type II flyash cement being lowest. Although the filling amount of the type II flyash cement was the lowest among the injection materials, it uniformly filled the voids.

From these results, we conclude that the Portland cement can be broadly filled densely for a long period, and

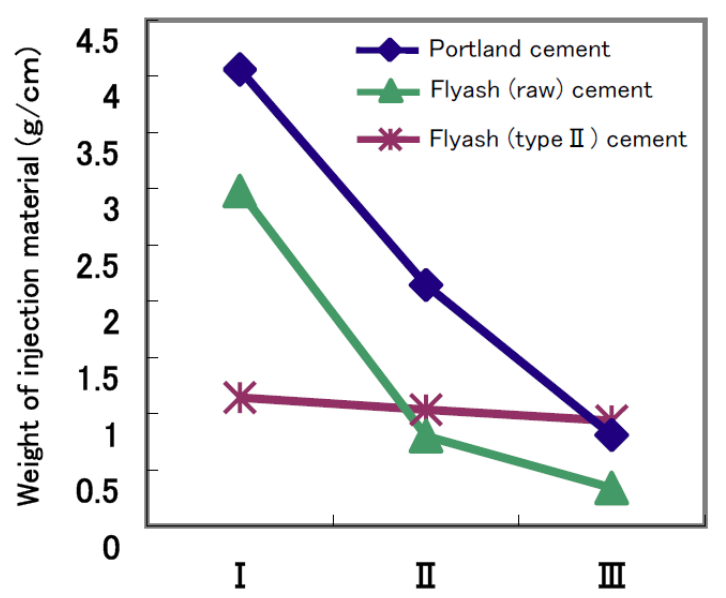

Figure 9. Weight of the injection material for each section. the raw flyash cement is suitable for narrow areas over a short time. Conversely, it seems that the type II flyash cement can be filled over a large area effectively.

\section{Conclusions}

In this paper, we attempt to clarify how much the size and shape of the flyash affects the properties of the injection mixture by way of an injection test. The results of the experiments are as follows:

1) The type II flyash cement has high fluidability compared with the Portland cement.

2) The Portland cement can be broadly filled densely for a long period, and the raw flyash cement is suitable for a narrow area over a short time.

3) The type II flyash cement can be filled over a large area effectively.

\section{REFERENCES}

[1] H. Shimada, T. Sasaoka, S. Kubota, K. Matsui and Y. Yoshida, "The Application of Fly Ash Cement in Mining Backfill Material," Proceedings of 12th International Symposium on Mine Planning and Equipment Selection, Kalgoorlie, 23-25 April 2003, pp. 199-204.

[2] T. Sasaoka, H. Shimada, M. Ichinose, S. Kubota and K. Matsui, "Utilization of Flyash as a Backfilling Material in Highwall Mining System," Proceedings of 3rd Asian Symposium on Engineering Geology and the Environment, Yogyakarta, 3-6 September 2001, pp. 263-272.

[3] A. A. Afrouz, "Placement of Backfill," Mining Engineer, 1994, pp. 205-211

[4] M. J. Carlson and L. W. Saperstein, "Efficient Use of Additives to Improve Pneumatically Emplaced Backfill Strength," Mining Engineer, 1989, pp. 462-466

[5] JFA (Japan Flyash Association), "Coal Ash Handbook," 1995.

[6] R. C. Joshi and E. A. Rosauer, "Pozzolanic Activity in Synthetic Ashes," American Ceramic Society Bulletin, Vol. 52, No. 5, 1973, pp. 456-463.

[7] R. C. Joshi and E. A. Rosauer, "Pozzolanic Activity in Synthetic Ashes," American Ceramic Society Bulletin, Vol. 52, No. 5, 1973, pp. 456-463.

[8] K. Sato and Y. Ito, "Clogging Mechanism and Time Dendence of Rock Mass Seepage," Tsuchi-to-Kiso, JSSMFE, Vol. 36, No. 4, 1988, pp. 21-25. (in Japanese) 